\title{
Submarine Ground-Water Discharge: Nutrient Loading and Nitrogen Transformations
}

Eutrophication of coastal waters due to nonpoint source land-derived nitrogen $(\mathrm{N})$ loads is a worldwide phenomenon and perhaps the greatest agent of change altering coastal ecology (National Research Council, 2000; Howarth and others, 2000). Within the United States, a majority of estuaries have been determined to be moderately to severely impaired by eutrophication associated with increasing nutrient loads (Bricker and others, 1999).

In coastal watersheds with soils of high hydraulic conductivity and permeable coastal sediments, ground water is a major route of transport of freshwater and its solutes from land to sea. Freshwater flowing downgradient from aquifers may either discharge from a seepage face near the intertidal zone, or flow directly into the sea as submarine ground-water discharge (SGD) (fig. 1). In the coastal aquifer, entrainment of saline pore water occurs prior to discharge, producing a gradient in ground-water salinity from land to sea, referred to as a subterranean estuary (Moore, 1999). In addition, processes including density-driven flow and tidal pumping create brackish and saline ground-water circulation. Hence, submarine ground-water discharge often consists of a substantial amount of recirculating seawater. Mixing of fresh and saline ground waters in the context of coastal sediments may alter the chemical composition of the discharging fluid. Depending on the biogeochemical setting, removal of fixed $\mathrm{N}$ due to processes leading to $\mathrm{N}_{2}$ (dinitrogen gas) production in the nearshore aquifer and subterranean estuary may significantly attenuate landderived $\mathrm{N}$ loads; or, processes such as ion exchange and tidal pumping in the subterranean estuary may substantially accelerate the transport of both land-derived and sediment re-mineralized $\mathrm{N}$ to estuarine water columns.

As emphasized by Burnett and others $(2001,2002)$, a fundamental problem in evaluating the importance of groundwater discharge in marine geochemical budgets is the difficulty of collecting samples across the salinity gradients of coastal aquifers. In addition, locating and quantifying rates of submarine groundwater discharge remains a challenge due to the diffuse and spatially and temporally heterogeneous nature of discharge. As a result, with regard to the study of biogeochemical cycles and chemical loads to coastal waters, the seepage face and subterranean estuary are relatively new and under-studied zones in the aquatic cascade from watershed to sea. Processes occurring in those zones must be understood and considered for proper modeling and management of coastal water resources.

\section{Approaches to Investigating Transformations}

To investigate controls on nutrient loads carried by submarine ground-water discharge, the U.S. Geological Survey (USGS) and Woods Hole Oceanographic Institution are examining ground-water flow, nutrient transport, and biogeochemistry in nearshore portions of coastal aquifers in a range of settings that contrast in terms of hydrogeology, land uses, and climate. This fact sheet describes research at sites in Waquoit Bay, Massachusetts, and in Tampa Bay, Florida. The biogeochemical investigations of nitro-

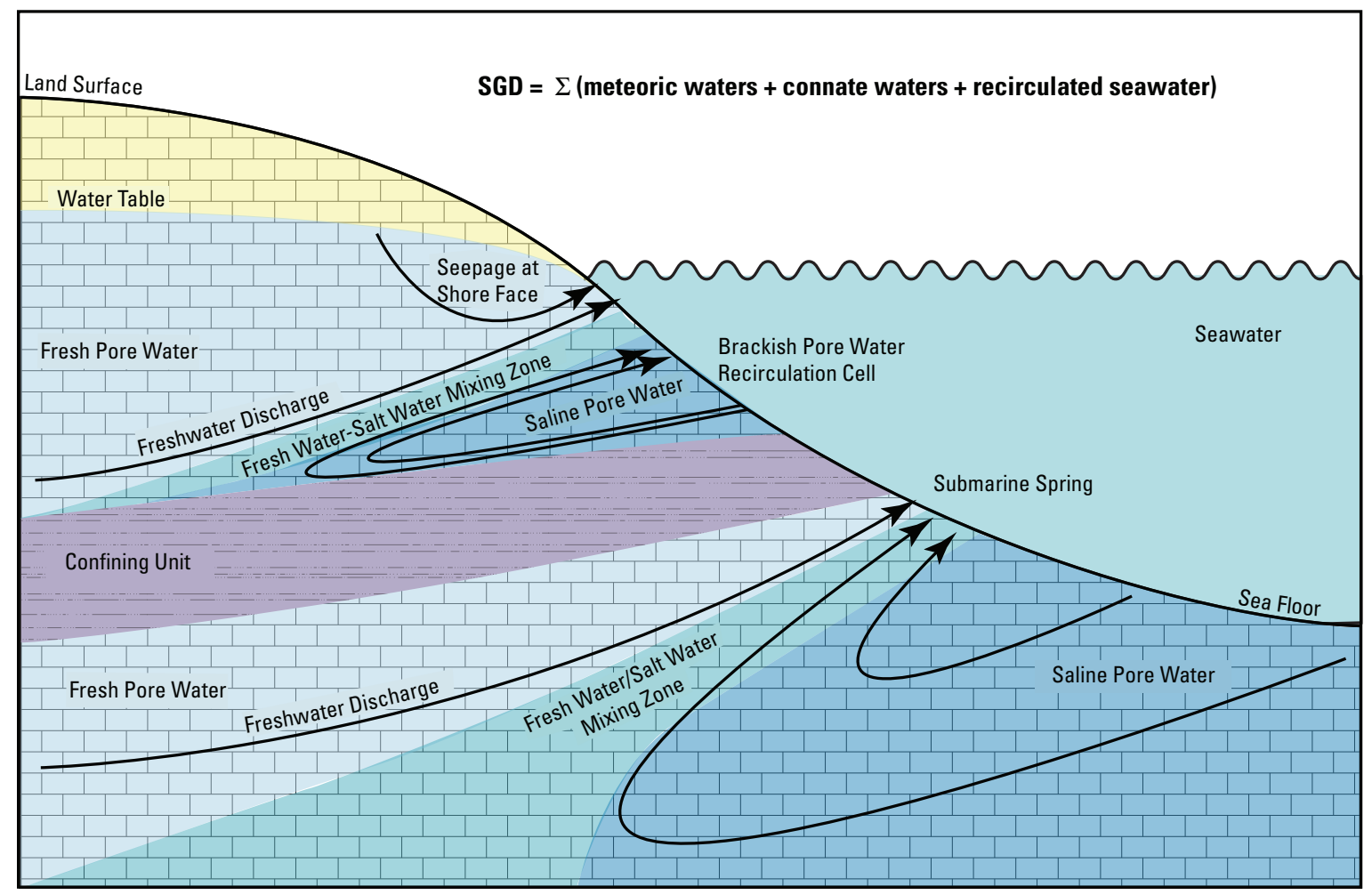

Figure 1. Crosssection of a submarine ground-water discharge zone (from Swarzenski, Bratton, and others, 2004). 
gen are being carried out in concert with examinations of radiochemical groundwater discharge tracers, seepage meter studies, and streaming resistivity surveys to identify locations and sources of submarine ground-water discharge and to quantify fluxes (Swarzenski and others, 2001; Talbot and others, 2003; Abraham and others, 2003; Swarzenski, Burnett and others, 2004; Swarzenski, Charette, and Langevin, 2004; Swarzenski, Bratton, and Crusius, 2004; and Crusius and others, 2005).

Our three primary areas of research with regard to $\mathrm{N}$ biogeochemistry in submarine ground-water discharge zones are:

1. Using naturally occurring $\mathrm{N}$ stable isotope ratios to trace fixed $\mathrm{N}$ loss.

2. Application of isotope pairing experiments to develop new understanding of the $\mathrm{N}$ cycle in coastal aquifers.

3. Using noble (inert) gases as tracers of $\mathrm{N}_{2}$ production.

\section{Nitrogen Stable Isotopic Ratios}

At the Waquoit Bay site the research team is using a stainless-steel drive point piezometer system to collect pore water samples in high-resolution vertical profiles. The samples are analyzed for a suite of biogeochemically cycled elements and tracers (Charette and Sholkovitz, 2006; Kroeger and Charette, unpublished data). The piezometer system allows profiles to be collected to a depth of 9 meters (m) or more with a sampling interval as small as $0.15 \mathrm{~m}$. The study is examining three major subsurface water masses with distinct biogeochemical characteristics: the nearshore freshwater aquifer, and two fresh and saline water mixing zones (referred to as shallow and deep subterranean estuaries).

The dominant pattern in nitrogen concentrations in the nearshore freshwater aquifer at the head of Waquoit Bay is the occurrence of both nitrate and ammonium plumes (fig. $2 A$ ) with concentrations exceeding 200 micromo$\operatorname{lar}(\mu \mathrm{M})$ in some locations. The nitrate and ammonium plumes were constant features during 3 years of sampling, but concentrations do vary over time.

Ammonium is the dominant form of nitrogen within the deep subterranean estuary, with maximum concentrations in individual profiles (40 to $70 \mu \mathrm{M}$ ) occurring at salinities of 26 to 28 , and at 5- to 8-m depths within the sediment (fig. $2 A$ and $2 C$ ). Brackish to saline pore waters are generally devoid of nitrate, have dissolved oxygen concentration from 0 to 3 milligrams per liter, and a low oxidation/reduction potential. During transport through the subterranean estuary, ammonium concentration generally suggests conservative behavior. The greatest concentrations of ammonium are at the highest salinity. The apparent conservative behavior of ammonium along the salinity gradient suggests that the preponderance of ammonification occurs at highest salinity, and that mixing and dilution are the dominant processes controlling ammonium concentration in the deep subterranean estuary. Based on radiochemical and hydrological estimates of fresh and saline ground-water discharge and on nitrogen concentrations in those zones, regenerated ammonium transport to the bay by advection of brackish to saline pore water is estimated to be in the range of 25 percent of the land-derived dissolved inorganic nitrogen load (Talbot and others, 2003; Abraham and others, 2003).

The co-occurrence of nitrate and ammonium is uncommon throughout the nearshore aquifer and subterranean estuary. The largely mutually exclusive distributions of nitrate and ammonium may be in part due to the loss of both $\mathrm{N}$ species in locations where advection brings nitrate-bearing waters with a low

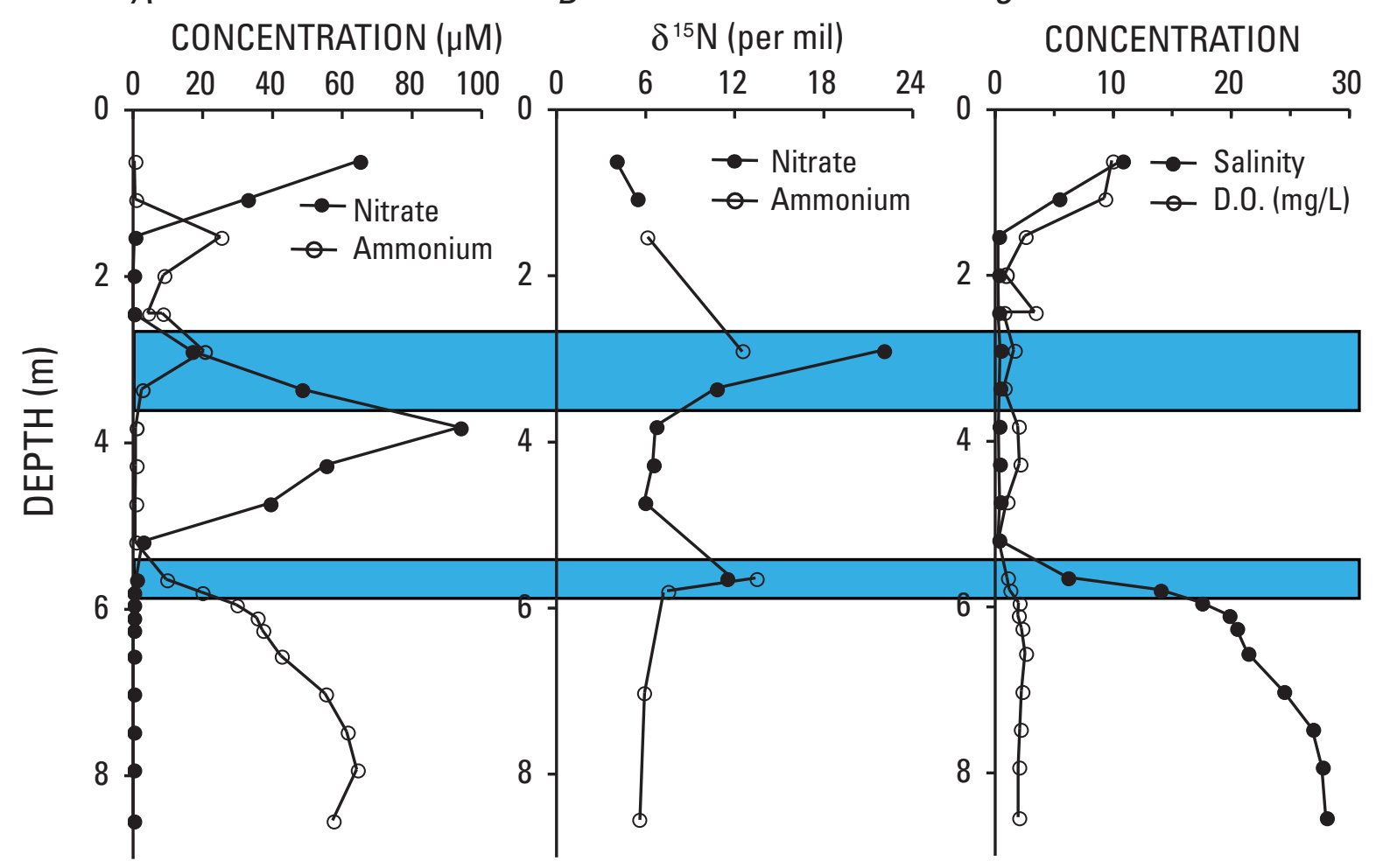

c 
dissolved-oxygen concentration into contact with relatively reducing ammoniumrich waters (fig. 2, blue shaded areas). In those mixing zones, a decrease in concentration and an increase in the nitrogen stable isotopic ratio in both nitrate and ammonium suggests concurrent loss of ammonium and nitrate, perhaps due to coupled nitrification/denitrification, or to other $\mathrm{N}_{2}$-producing microbial processes (fig. $2 A$ and $2 B$ ).

The pattern of nitrogen loss shown in figure 2 is a consistent one, observed in a number of locations in both fresh and saline portions of the nearshore aquifer. Mixing of the nitrate and ammonium plumes in the freshwater zone may be related in part to compression of groundwater flow lines associated with thinning of the freshwater aquifer near the seepage face. Denitrification of land-derived nitrate at low salinity within the subterranean estuary (fig. 2, blue shaded area at 5.5-m depth) may (1) provide an explanation for the absence of nitrate in brackish and saline subterranean waters and (2) suggest that transformations occurring within subterranean estuaries do have the potential to modify land-derived nitrogen loads prior to discharge to the sea.

\section{Isotope Pairing}

There has been a dramatic increase in recent years in the number of microbial $\mathrm{N}$ transformation pathways that have been shown or proposed to occur in marine environments (Luther and others, 1997; Hulth and others, 1999; Zehr and Ward, 2002). Of particular importance among the "new" $\mathrm{N}$ transformations is anaerobic ammonium oxidation (anammox) (fig. 3), a microbial process that in some settings occurs at significant rates at the ecosystem scale (Dalsgaard and others, 2003; Kuypers and others, 2003). Anammox has not been previously investigated in submarine ground-water discharge zones, and yet preliminary evidence from isotope pairing experiments at Waquoit Bay suggests that it may be an important pathway for $\mathrm{N}_{2}$ formation in those environments.

With academic collaborators at the Woods Hole Oceanographic Institution, the study team is developing methods to investigate the consequences of advection through permeable sediments on $\mathrm{N}$ transport and transformations via a series of batch incubation experiments and flow-through experiments designed to simulate water transport through permeable marine sediments. The study is particularly focused on loss of fixed nitrogen due to production of $\mathrm{N}_{2}$, and will involve a combined approach of isotope pairing
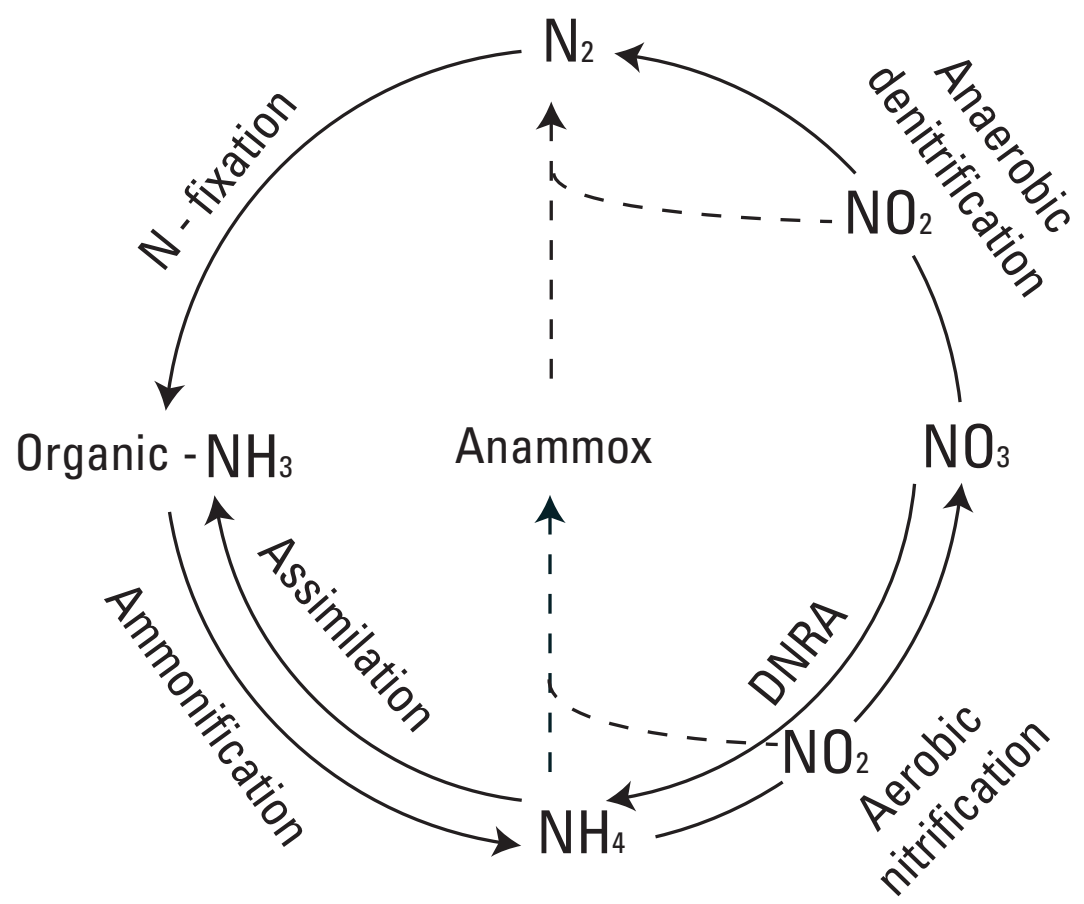

Figure 3. A simplified nitrogen $(\mathrm{N})$ cycle highlighting the role of anammox. Anammox short circuits the pathway to nitrogen gas $\left(\mathrm{N}_{2}\right)$ production by circumventing the coupling of aerobic nitrification to denitrification. Note the depiction of nitrite $\left(\mathrm{NO}_{2}^{-}\right)$as an intermediate in nitrification, denitrification, or dissimilatory nitrate reduction to ammonium (DNRA). (Modified from Trimmer and others, 2003). Abbreviations are as follows: $\mathrm{NO}_{2}$, nitrite; $\mathrm{NO}_{3^{\prime}}$, nitrate; $\mathrm{NH}_{4^{\prime}}$ ammonium; $-\mathrm{NH}_{3^{\prime}}$ reduced nitrogen in organic form.

and membrane inlet mass spectrometry with molecular biology to quantify and identify pathways of $\mathrm{N}_{2}$ production.

\section{Noble Gases as Tracers}

With collaborators at the Marine Biological Laboratory, Woods Hole, and the Woods Hole Oceanographic Institution, the USGS study team is estimating the magnitude of $\mathrm{N}_{2}$-producing processes within the range of biogeochemical zones occurring within freshwater, brackish, and saline aquifers. Membrane inlet mass spectrometry (MIMS) is used for rapid analysis of $\mathrm{N}_{2}$ and argon concentrations in ground water. Measured $\mathrm{N}_{2}$ concentrations will be compared to concentrations expected in the absence of in-aquifer $\mathrm{N}_{2}$ production to calculate concentration of excess $\mathrm{N}_{2}$. Complications in the interpretation of dissolved gas concentrations in ground water are (1) uncertainty regarding water temperature at the time of recharge to the aquifer, which will determine the inherited $\mathrm{N}_{2}$ /argon (Ar) ratio and (2) the presence of excess air due to entrapment of air bubbles at the time of recharge (Heaton and Vogel, 1981), followed by partial or complete dissolution of the trapped gases (Peeters and others, 2002). After recharge, hydrostatic pressure and bubble surface tension tend to cause bubble dissolution and oversaturation of gases. Since $\mathrm{N}_{2}$ concentration/Ar concentration in air is greater than in water at saturation, bubble entrapment would tend to increase measured $\mathrm{N}_{2} / \mathrm{Ar}$ in ground water and may result in overestimation of denitrification. To estimate concentrations of dissolved gases due to bubble entrapment and to constrain estimates of temperature at recharge, a subset of samples will be analyzed in the laboratory at the Woods Hole Oceanographic Institution for the full suite of noble gas concentrations by peak-height manometry using combined magnetic sector and quadrupole mass spectrometry. For those analyses, a set of samples will be obtained in stainless steel transfer vessels, and vacuum extracted in the laboratory for storage in glass ampoules. The gas samples will be chemically purified and cryogenically separated for mass spectrometric analysis. Based on the results of those analyses, recharge temperature, bubble entrapment, and the extent of bubble dissolution can be modeled.

Estimates of $\mathrm{N}_{2}$ production in freshwater aquifers are being compared to estimates of land-derived, ground-water transported nitrogen loads to coastal waters. Those comparisons will provide an important test of hypotheses regard- 
ing the behavior of $\mathrm{N}$ during transport through watersheds and of $\mathrm{N}$ loading models used to manage coastal watersheds and coastal waters. In addition, the study will test for $\mathrm{N}_{2}$ production in mixing zones between fresh and saline ground water.

\section{References Cited}

Abraham, D.M., Charette, M.A., Allen, M.C., Rago, A., and Kroeger, K.D., 2003, Radiochemical estimates of submarine groundwater discharge to Waquoit Bay, Massachusetts: The Biological Bulletin, v. 205, p. 246-247.

Bricker, S.B., Clement, C.G., Pirhalla, D.E., Orlando, S.P., and Farrow, D.R.G., 1999, National estuarine eutrophication assessment-Effects of nutrient enrichment in the nation's estuaries: National Oceanic and Atmospheric Administration, National Ocean Service, Special Projects Office and the National Centers for Coastal Ocean Science, Silver Spring, Md.

Burnett W.C., Taniguchi, M., and Oberdorfer, J., 2001, Measurement and significance of the direct discharge of groundwater into the coastal zone: Journal of Sea Research, v. 46, p. 109-116.

Burnett W., Chanton J., Christoff, J., Kontar, E., and others, 2002, Assessing methodologies for measuring groundwater discharge to the ocean: EOS, v. 83 , no. 11, p. $117,122,123$.

Charette, M.A., and Sholkovitz, E.R., 2006, Trace element cycling in a subterranean estuary-Part 2. Geochemistry of the pore water: Geochimica et Cosmochimica Acta, v. 70, p. 811-826.

Crusius, J., Koopmans, D., Bratton, J., Charette, M.A., Kroeger, K.D., Ryckman, L., Halloran, K., and Colman, J., 2005, Submarine groundwater discharge to a small estuary estimated from radon and salinity measurements and a box model: Biogeosciences Discussions, v. 2, p. 1-35.

Dalsgaard, T., Canfield, D.E., Petersen, J., Thamdrup, B., and Acuna-Gonzalez, J., 2003, $\mathrm{N}_{2}$ production by the anammox reaction in the anoxic water column of Golfo Dulce, Costa Rica: Nature, v. 422, p. 606-608.

Heaton, T.H.E., and Vogel, J.C., 1981, "Excess air" in groundwater: Journal of Hydrology, v. 50, p. 201-216.

Howarth, R.W., and others, 2000, Nutrient pollution of coastal rivers, bays, and seas: Issues in Ecology, v. 7, p. $1-15$.

Hulth, S., Aller, R.C., and Gilbert, F., 1999, Coupled anoxic nitrification/ manganese reduction in marine sedi- ments: Geochimica et Cosmochimica Acta, v. 63, p. 49-66.

Kuypers, M.M.M., Sliekers, A.O., Lavik, G., Schmid, M., Jorgensen, B.B., Kuenen, J.G., Damste, J.S.S., Strous, M., and Jetten, M.S.M., 2003, Anaerobic ammonium oxidation by anammox bacteria in the Black Sea: Nature, v. 422, p. 608-611.

Luther, G.W., Sundgy, B., Lewis, G.L., Brendel, P.G., and Silverberg, N., 1997, Interactions of manganese with the nitrogen cycle-Alternative pathways to dinitrogen: Biochimica et Biophysica Acta, v. 61, p. 4043-4053.

Moore, W.S., 1999, The subterranean estuary-A reaction zone of ground water and sea water: Marine Chemistry, v. 65, p. 111-125.

National Research Council, 2000, Clean coastal waters-Understanding and reducing the effects of nutrient pollution: National Academy Press, Washington, D.C.

Peeters, F., Beyerle, U., Aeschbach-Hertig, W., Holocher, J., Brennwald, M.S., and Kipfer, R., 2002, Improving noble gas based paleoclimate reconstruction and groundwater dating using ${ }^{20} \mathrm{Ne} /{ }^{22} \mathrm{Ne}$ ratios: Geochimica et Cosmochimica Acta: v. 67, p. 587-600.

Swarzenski, P.W., Reich, C.D., Spechler, R.M., Kindinger, J.L., and Moore, W.S., 2001, Using multiple geochemical tracers to characterize the hydrogeology of the submarine spring off Crescent Beach, Florida: Chemical Geology, v. 179, p. 187-202.

Swarzenski, P.W., Burnett, B., Reich, C., Dulaiova, H., Martin R., and Meunier, J., 2004, Novel geophysical and geochemical techniques to study submarine groundwater discharge in Biscayne Bay, Florida: U.S. Geological Survey Fact Sheet 2004-3117, 1 folded sheet (4 p.).

Swarzenski, P.W., Charette, M., and Langevin, C., 2004, An autonomous, electromagnetic seepage meter to study coastal groundwater/surface water exchange: U.S. Geological Survey Open-File Report 2004-1369, 1 folded sheet (4 p.).

Swarzenski, P.W., Bratton, J., and Crusius, J., 2004, Submarine groundwater discharge and its role in coastal processes and ecosystems: U.S. Geological Survey Open-File Report 2004-1226, [4] p.

Talbot, J.M., Kroeger, K.D., Rago, A., Allen, M.C., and Charette, M.A., 2003, Nitrogen flux and speciation through the subterranean estuary of Waquoit Bay, Massachusetts: The Biological Bulletin, v. 205, p. 244-245.
Trimmer, M., Nicholls, J.C., and Deflandre, B., 2003, Anaerobic ammonium oxidation measured in sediments along the Thames Estuary, United Kingdom: Applied and Environmental Microbiology, v. 69, p. 6447-6454.

Zehr, J.P., and Ward, B.B., 2002, Nitrogen cycling in the ocean-New perspectives on processes and paradigms: Applied and Environmental Microbiology, v. 68, p. 1015-1024.

\section{Acknowledgments}

We thank our collaborators on these projects: Edward Sholkovitz, William Jenkins, Karen Casciotti, Katrina Edwards (Woods Hole Oceanographic Institution), Anne Giblin and Jane Tucker (Marine Biological Laboratory), Dirk Koopmans, Christopher Reich, Brian Blake-Collins, Jason Greenwood (USGS). Laurinda Travers, Betsy Boynton, Debra Foster, and Iris Collies aided with document preparation.

\section{Related Links}

USGS Submarine Groundwater Discharge Program: http://coastal.er.usgs.gov/sgd/

Coastal Groundwater Geochemistry (WHOI): http://www.whoi.edu/science/ MCG/groundwater/

Novel geophysical and geochemical techniques used to study submarine groundwater discharge in Biscayne Bay, Florida: http://sofia.usgs.gov/publications/fs/20043117/

An autonomous, electromagnetic seepage meter to study coastal groundwater/surface-water exchange: http://sofia.usgs. gov/publications/ofr/2004-1369/

Submarine Ground-Water Discharge and Its Influence on Coastal Processes and Ecosystems: http://soundwaves.usgs.gov/2004/06/ research4.html

Oceanus magazine article "Water Flowing Underground": http://www.whoi.edu/oceanus/viewArticle.do?id=2485

By Kevin D. Kroeger ${ }^{1}$, Peter W. Swarzenski², John Crusius ${ }^{1}$, John F. Bratton ${ }^{1}$ and Matthew A. Charette ${ }^{3}$

${ }^{1}$ U.S. Geological Survey, Woods Hole, Mass. ${ }^{2}$ U.S. Geological Survey, St. Petersburg, Fla.

${ }^{3}$ Woods Hole Oceanographic Institution, Woods Hole, Mass.

Contact Information:

Kevin D. Kroeger

U.S. Geological Survey

Woods Hole Science Center

384 Woods Hole Rd.

Woods Hole, MA 02543

508-457-2270

kkroeger@usgs.gov 